\title{
Job Safety Analysis and Hazard Identification of Welding Process in Semarang - JSA Method AS/NZS 4360:2004
}

\author{
Ratih Pramitasari ${ }^{1 *}$, Haikal ${ }^{1}$, MG Catur Yuantari ${ }^{1}$, Kristin Ishak Kurnia Dwi ${ }^{1}$, Chalobon \\ Treesak $^{2}$ \\ ${ }^{1}$ Faculty of Health Sciences, Universitas Dian Nuswantoro, Indonesia \\ ${ }^{2}$ Khon Kaen University, Thailand \\ *corresponding author, email: ratih.pramitasari@dsn.dinus.ac.id
}

\section{ARTICLE INFO}

Article history

Received 08/03/21

Revised 11/16/21

Accepted 11/22/21

Keywords

welders

welding

analysis

risk

\begin{abstract}
Background: The welding workshop in Semarang City is spread over several areas in Semarang City. There are several types of work in welding workshops, namely, cutting raw materials, assembling, welding, grinding, sanding, and painting. This study aimed to analyze occupational safety and health risks in the informal welding workshop using the JSA (Job Safety Analysis) AS/NZS 4360:2004 Risk Management method. Method: This research was conducted using semi-quantitative method with descriptive analysis. A cross-sectional research design was used because data (observations, interviews, filling in risk analysis tables, work accidents, occupational diseases, and controls) were collected at a particular time. The study was conducted in Semarang, Central Java, and the population was all informal welding workshops. Result: This study showed that there are 8 types of welding tasks, 21 potential hazards, and 24 health consequences in a welding process. The total score calculated by multiplying "chance" by "severity" shows that 11 health consequences were acceptable risk while 13 others were high risk. Conclusion: The highest score of occupational health hazards was electric shock due to chipped cable, electric shock due to a chipped short circuit, and wet/rain/cloudy work area. Welders are recommended to follow the proper instruction in the welding process, and each workshop must provide a first aid box for its workers.
\end{abstract}

This is an open access article under the CC-BY-SA license.

\section{Introduction}

Occupational health and safety are one of the aspects of labor protection that aims to provide workers with a comfortable and safe working condition so that they can achieve an optimal increase of productivity. Therefore, every workplace must promote and maintain the wellbeing of its workers [1]. Based on the data from National Social Security (Badan Penyelenggara Jaminan Sosial Ketenagakerjaan, BPJAMSOSTEK) Central Java and DIY, as of February 2020, more than 21 billion rupiahs disbursement have been disbursed from the work accident benefit (Jaminan Kecelakaan Kerja, JKK) program for 4,503 cases of work accidents. In addition, the Casualty Security Program (Jaminan Kematian) has disbursed a compensation with a total value of twenty billion rupiah for 623 death cases.

Every has a potential risk of danger in the form of work accidents. The magnitude of the potential for accidents and occupational diseases depends on the type of production, the technology used, materials used, labor, and the welding workshop industry [2]. Welding workshop is one of the types of informal industry that involves various sources of hazards in its works, such as electricity, gas, grinding [3]. An employee of the Arto Moro welding workshop, located in Dilem Village, Kepanjen District died in a work accident. The victim was declared dead 
while welding the wheels of a truck. This case is consistent with the research of Helna who stated that cases of accidents in welding workers reached $57.6 \%$ [4].

In addition to cases of work accidents which are pretty high, welding workers are also at risk of experiencing Musculoskeletal Disorders (MSDs) complaints (56.7\%) [5,6]. A study also reported that a significant number of welding workers suffer from eye disorders $(50.0 \%)$ which are mainly influenced by age, work period, and the use of glasses [7]. Factors causing work accidents in welding workers include work tool preparation behavior, welding behavior, lifting behavior, and age [3]. Potential hazards that are often found in welding workshop workers are improper use of Personal Protective Equipment (PPE) (58.1\%) [8], working period of more than five years $(64.9 \%)$, and $5-8$ hours extended exposure to welding equipment $(52.7 \%)$ [9]. The habit of being too close to the equipment in the welding process, namely less than $52 \mathrm{~cm}$, also increases the risk of injury. Several studies reported that a significant number of respondents had the habit of being too close to the equipment in the welding process $(55.4 \%)$ and $(50.0 \%)$ respectively $[10,11]$. A study regarding potential hazards at the AUTO 2000 Workshop, Plaju Palembang branch revealed that noise was categorized as high-risk while lighting, dust (TSP), gas (CO, NO2, SO2), solvent, heavy metal, food sanitation, and ergonomic factors were medium-risk category, and vibration was categorized as low-risk [12].

Welding workshop is an informal sector industry. Welding workshops make iron construction and the like, such as iron fences or doors, safety trellises or window trellises, stairs, canopies, roof frames, and others. The application of the principles of occupational safety and health in this sector is still fragile. Law No. 13 of 2003 concerning Manpower states that every organization must implement occupational safety and health measures to protect the safety of workers while Article 87 of this Law states that every company is required to have an Occupational Health and Safety Management System (SMK3) that is integrated with other company management departments. It is necessary to comply with the law in Indonesia, minimize work accidents, and identify the potential hazards in the work environment. Related to this, Job Safety Analysis (JSA) method can be used to identify and control potential hazards [13].

\section{Materials and Method}

This study took the form of semi-quantitative research with a descriptive analysis. A crosssectional research design was used because data were collected (observations, interviews, filling in risk analysis tables, work accidents, occupational diseases, and controls) at a particular time using the JSA AS/NZS 4360:2004 Risk Management method. The study was conducted in Semarang, Central Java, over a period of four months. The population was 14 informal welding workshops with 31 welders. Samples were determined using total sampling technique.

Primary data were collected through observation and interview. The data include: 1) information on the tools and materials used in the welding process; 2) each of the stages in the welding process; 3 ) work accidents experienced by workers in the welding workshop; and 4) Physical, Chemical, Biological, Physiological, Ergonomic, and Psychosocial risk factors. The instruments of this research were observation checklist, interview guideline, JSA (Job Safety Analysis) worksheet, recording machine, and camera. Data were analyzed using SPSS software to obtain frequency distribution data. Risk Assessment was conducted using JSA AS/NZS 4360:2004 Risk Management method and categorized based on Table 1 and 2 below [14]. This study has been approved by the ethical committee of Faculty of Health Sciences Universitas Dian Nuswantoro (No. 100/EA/KEPK-Fkes-UDINUS/VII/2021). We obtained permission from the Head of Welding Workshop Association at Stadion Diponegoro Area. Respondents were required to share pictures of the working procedures and health risk hazards at their welding workshop.

\begin{tabular}{cll}
\hline $\begin{array}{l}\text { Level } \\
\text { (degree) }\end{array}$ & $\begin{array}{l}\text { Description criteria for chance } \\
\text { of Occupational Health Issue }\end{array}$ & $\begin{array}{l}\text { Description criteria for severity of } \\
\text { occupational health issue }\end{array}$ \\
\hline 1 & Rare (very low incidence rate) & $\begin{array}{l}\text { Incident or accident can be managed by a } \\
\text { first aid (minimal risk) } \\
\text { Incident or accident can be treated by } \\
\text { medical treatment and healthcare team } \\
\text { (moderate risk) }\end{array}$ \\
3 & Low (once every 5-10 years) & $\begin{array}{l}\text { Incident or accident causes severe illness or } \\
\text { injuries (high risk) } \\
\text { Incident or accident causes death or is life } \\
\text { threatening (severe risk) }\end{array}$ \\
\hline
\end{tabular}


Table 2 Description of Total Scores for Occupational Health Issue Risk Level

\begin{tabular}{ll}
\hline Total Score & Description Criteria for Risk Level \\
\hline $1-2$ & Minimal risk \\
$3-7$ & Acceptable risk; Need to review working procedure and control of \\
& hazard \\
$8-11$ & High risk; Need to manage and control \\
$12-16$ & $\begin{array}{l}\text { No acceptable risk or tolerance; Need to stop and provide a control } \\
\text { method or procedure in order to restart }\end{array}$ \\
\hline
\end{tabular}

\section{Results and Discussion}

\subsection{Results}

Welding tasks in a welding workshop consists of preparing the material to be welded, climbing stairs/scaffolding for welding at high places and confined space, cleaning the material on the object to be welded, connecting mass bag and electrode cable, connecting grounding to material, turning on the welding box panel and adjusting the electric current, welding work materials with electric/carbide/argon welding in open places, heights, and confined spaces. The main sources of hazards during welding process included sharp materials, wet floor, fragile stairs, confined space, dust and particles, electricity, fire sparks, unsafe work behavior, and unsafe workplace conditions. (Figure 1a). The main sources of hazards during welding process included sharp materials, wet floor, fragile stairs, confined space, dust and particles, electricity, fire sparks, unsafe work behavior, and unsafe workplace conditions. These hazard sources can cause injuries, cut, bruises, electric shock, burns, fracture, and respiratory disorders.

In a welding process, there are 8 types of welding task, 21 potential hazards, and 24 health consequences. The total score calculated by multiplying "chance" by "severity" shows that 11 health consequences were acceptable risk and 13 health consequences were high risk. The high-risk level hazards included slips and falls due to unsafe workplace conditions such as fragile stairs, confined space, wet floor, and untidy workplace. Other highrisk level hazards are electric shock from chipped short circuit and cable, burns from fire sparks due to welding equipment, respiratory disorders from inhaling dust and particles, and unsafe work behavior such as not wearing a body harness. The highest score of occupational health hazards was electric shock. More details are presented in Table 3.

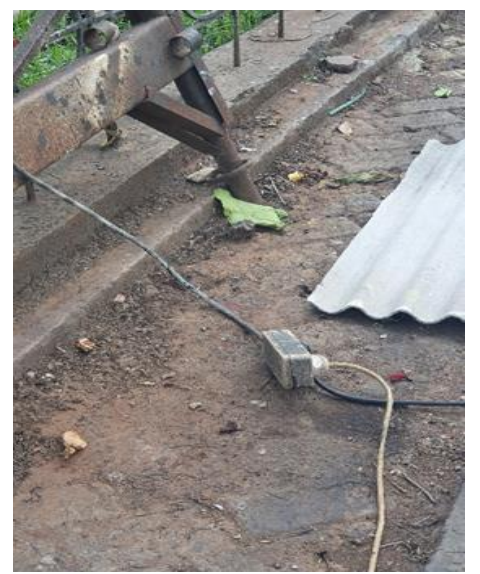

(a)

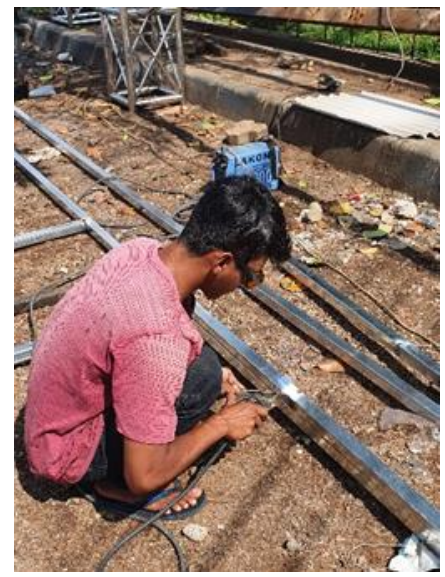

(b)

Figure 1. (a) Workplace condition (untidy cables); (b) Welders fusing stainless steel using electric welding Source: Primary data 


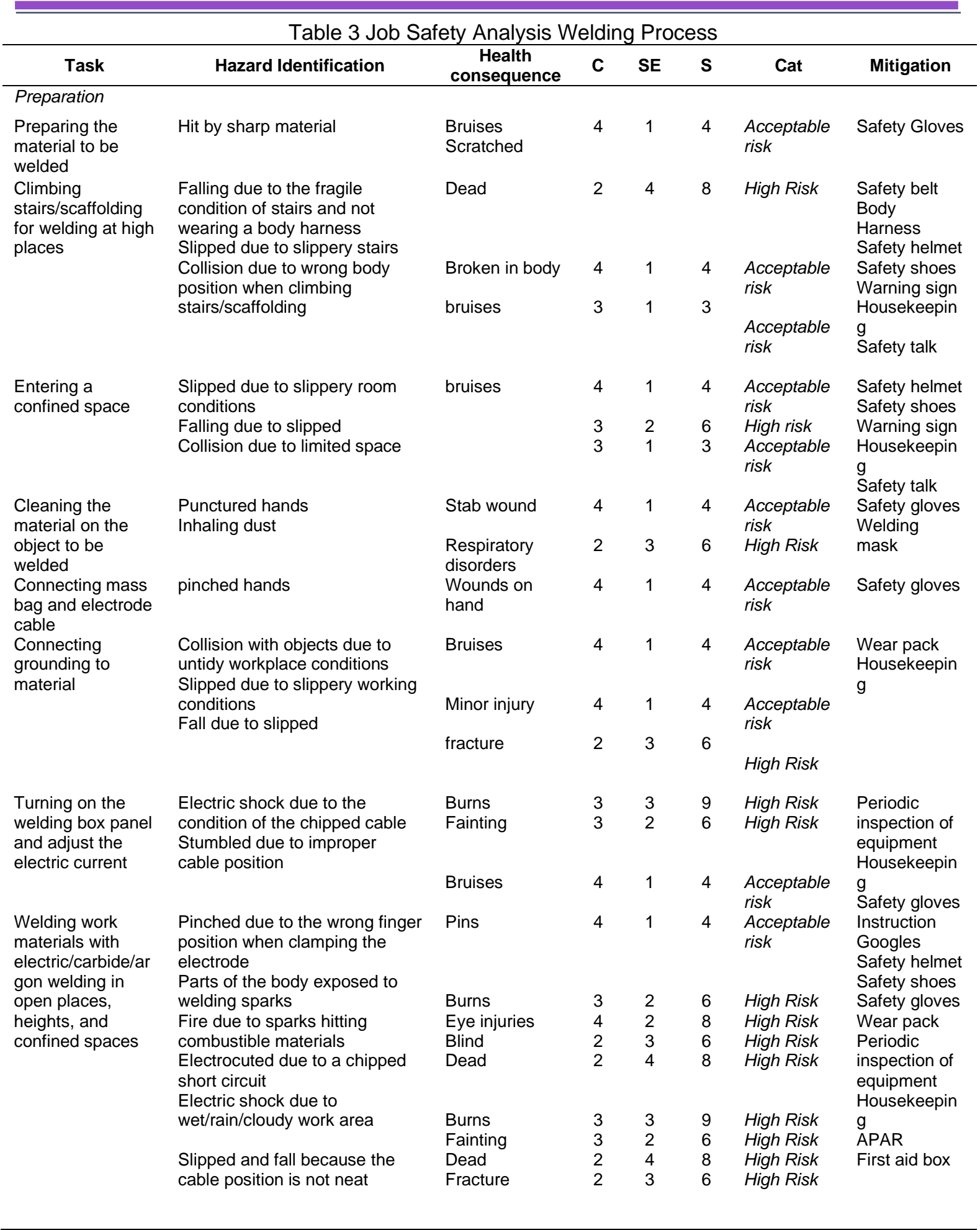

Source: Primary data

Notes:

$\mathrm{C}=$ Chance SE = Severity S = Score Cat = Category 


\subsection{Discussion}

Primary data were obtained through interviews, namely searching for information directly from the field about the causes of welding hazards to workers. We also took photos of welding activities at several welding workshops and identified the potential hazards that exist. To support the research, we reviewed some literature related to the potential hazards of welding activities. Welding is the process of fabricating two or more materials based on the principles of diffusion process, resulting in the unification of the parts of materials being fused. Welded materials are lightweight, strong, easy to be assembled, and economical. Therefore, there is quite the demand in the market for welded materials.

The results of the analysis on occupational safety hazards in welding are presented in Table 3. Based on the identification and risk assessment, 13 activities were included in the high-risk category. The highest score of the occupational health hazard was electric shock. Although electric shock got the highest score, the occurrence of this incidence is low because most welding workers are quite skilled and understand the impact of chipped cables during welding activities. However, this has happened to several welding workers, so the probability value of this activity is 3 , which means electric shock because the cable is peeled off only happens once a year. Health risks to workers due to electric shock can be in the form of burns or even unconsciousness because the electric current used for the welding process reaches 500 amperes with a voltage of about 28-45 voltages [15] so that the risk of severity is given a score of 3 . The results of this study are in line with an earlier study, which stated that in the welding process at the Wijaya welding workshop, the severity value of short-circuit electric shock was 9. Trips or collision with electric equipment also might lead to electric shock [16]. Several other studies have also stated that electric shock in the welding process is the highest risk of danger that often occurs in the welding process [13,17-18].

Another cause of electric shock is welding in the wet/rain/cloudy work area. Welding workers work according to the demand, so they have targets to complete.In order to meet work targets, workers often neglect safety by continuing to do welding even in cloudy or even rainy conditions. Based on research on the effect of weather variations on the toughness of welds on low carbon steel, it is not allowed to do welding in cloudy or rainy conditions. Therefore, this activity is rated 3 for the chance of occurrence, meaning that it does not occur every day but quite often with a span of 6 months to 1 once a year. In a similar study on risk assessment, it was found that the risk of electric shock to welding workers was considered as high [19]. As a result of hazardous activities and unsafe conditions, workers can suffer burns or become unconscious and even die from electric shock or lightning strikes. The results of this study are in line with previous studies which reported that when welding in drizzling weather $\left(23^{\circ} \mathrm{C}\right)$, the tensile stress was $6.4 \%$ higher and the hardness value was $1.05 \%$ smaller than the parent metal [20].

The second high risk level hazards were falls due to fragile stairs and burns due to sparks from combustible materials. The risk of falling when climbing stairs or scaffolding occurs in workers who do welding at high places, such as installing billboards, canopies, or building construction. Workers will be provided with a body harness only when working for large industries such as advertising or high-rise building construction. Workers in a small scales welding industry work without personal protective equipment because they have to provide it themselves [21]. Workers will continue to work even though they are not equipped with appropriate personal protective equipment, so the potential danger of falling when climbing stairs or scaffolding is possible. However, this rarely happens because workers are used to it, so the probability value is 2 . The severity value if falling from a high elevation can be fatal to workers, so it is given a value of 4 because it might result in death [13].

Fires that occur due to sparks hitting flammable materials rarely occur in welding workshops. Although the work area in the workshop tends to be untidy, workers in welding workshops are aware not to put flammable materials around them when doing welding. Thus, the probability of occurrence is 2 . However, if it occurs, then the impact obtained can be fatal. In addition to material losses, it can also lead to death because there are gas cylinders and the amount of electricity in the welding workshop area can cause an explosion in the event of a fire. This result is also in line with Johannes' research, which stated that work that involves fire is prone to for fire and explosion [22]. The occurrence of respiratory problems due to inhaling fume particles during welding is also one of the potential hazards for welding workers. This is in line with the research by Kjell Toren in Sweden, who reported that welding can increase the risk of getting invasive pneumococcal disease [23]. Another study on the occupational exposure to stainless steel welding fumes conducted by 
Stanislawska, stated that manganese, chromium, and nickel were found in the blood of welders as a result of exposure to fume particles [24-25].

The last potential hazard that frequently occurs in welding workshops is being hit by fire sparks from welding equipment. A score of 4 was given because workers frequently experience this incidence. Previous research reported that $100 \%$ welding workers at CV. Cahaya Tiga Putri have been hit by sparks, especially in the eyes [1]. The body parts most frequently exposed to welding sparks are the eyes and hands. Workers in welding workshops rarely wear personal protective equipment, especially when welding with carbide and electric welding. Most workers feel uncomfortable when wearing protective clothing. They also feel that wearing protective clothing hinders their movements and makes them less productive. Thus, they often experience eye injuries, eye irritation, and slight burns on their hands. Workers are used to the condition of eye irritation that they experience [26]. Workers who do not wear glasses tend to suffer from red eyes [7]. This finding is in agreement with Suheri's finding which showed that the greatest health consequence on welders is visual impairment $[18,27]$. The form of treatment they do is to take pain relievers at night and return to work in the morning [28]. This finding also matches with the research of Karl Kafui, who reported that $47.9 \%$ of welding workers suffered injuries to their eyes due to fire sparks [29]. Another health impact is eye fatigue due to prolonged exposure to welding [30].

\section{Conclusion}

This study shows that there are 8 types of welding task, 21 potential hazards, and 24 health consequences in a welding process. JSA and hazard identification on welding process revealed that 11 health consequences were acceptable risk while 13 others were categorized as high risk. The high-risk level hazards included falls due to climbing fragile stairs, not wearing a body harness, slips due to entering confined space, respiratory disorders due to inhaling dust and particles, burns due to getting exposed to welding sparks and combustible materials, electric shock due to a chipped short circuit and wet/rain/cloudy work area, and slips and falls due to untidy workplace and wet floor. All workers are strongly recommended to follow the proper instruction for the welding process. In addition, each welding workshop must provide a first aid box. The findings of this study can be used to create an action plan for reducing the occupational health hazards in Para rubber sawmills.

\section{Declaration}

Acknowledgments: We would like to express our gratitude to the Faculty of Health Sciences as an affiliate and LPPM Dian Nuswantoro University for the research grant.

Conflicts of Interest: The authors declare no conflict of interest. The founding sponsors had no role in the study's design, in the collection, analyses, or interpretation of data, in the writing of the manuscript, and in the decision to publish the results.

\section{References}

1. Esmail RY, Sakwari GH. Occupational Skin Diseases among Building Construction Workers in Dar es Salaam, Tanzania. Ann Glob Health. 2021 Sep 23;87(1):92. doi: 10.5334/aogh.3102. PMID: 34621627; PMCID: PMC8462472.

2. Piché-Renaud PP, Groves HE, Kitano T, Arnold C, Thomas A, Streitenberger L, Alexander L, Morris SK, Science M. Healthcare Worker Perception of a Global Outbreak of Novel Coronavirus (COVID-19) and Personal Protective Equipment: Survey of A Pediatric Tertiary-Care Hospital. Infect Control Hosp Epidemiol. 2021 Mar;42(3):261-267. doi: 10.1017/ice.2020.415. Epub 2020 Aug 12. PMID: 32782038; PMCID: PMC7468688.

3. Hassan SM, Nasir U, Anwar K, Talib U. An Assessment of the Level of Awareness and Reported Complaints Regarding Occupational Health Hazards and the Utilization of Personal Protective Equipments Among the Welders of Lahore, Pakistan. Int J Occup Environ Health. 2017 Apr;23(2):98-109. doi: 10.1080/10773525.2018.1426259. Epub 2018 Jan 17. PMID: 29338641 ; PMCID: PMC6060853.

4. Gonçalves SBB, Sakae TM, Magajewski FL. Prevalence and Factors Associated with Work Accidents in A Metal-Mechanic Company. Rev Bras Med Trab. 2018 Mar 1;16(1):26-35. doi: 10.5327/Z1679443520180086. PMID: 32270071; PMCID: PMC7104819. 
5. Burgess-Limerick R. Participatory ergonomics: Evidence and Implementation Lessons. Appl Ergon. 2018 Apr;68:289-293. doi: 10.1016/j.apergo.2017.12.009. Epub 2017 Dec 20. PMID: 29409647.

6. Chaiklieng S. Health Risk Assessment on Musculoskeletal Disorders Among Potato-Chip Processing Workers. PLoS One. 2019 Dec 3;14(12):e0224980. doi: 10.1371/journal.pone.0224980. PMID: 31794549; PMCID: PMC6890250.

7. Chen H, Duan J, Yang Z, Xiong W, Deng L. Picosecond Laser Seal Welding of Glasses with a Large Gap. Opt Express. 2019 Oct 14;27(21):30297-30307. doi: 10.1364/OE.27.030297. PMID: 31684279.

8. Lewis J. Welding Safety Best Practices. Occup Health Saf. 2017 Apr;86(4):22-3. PMID: 30281272.

9. Kwaku Tetteh KK, Owusu R, Axame WK. Prevalence and Factors Influencing Eye Injuries among Welders in Accra, Ghana. Adv Prev Med. 2020 Sep 16;2020:2170247. doi: 10.1155/2020/2170247. PMID: 33014472; PMCID: PMC7516735.

10. Zahiri Harsini A, Ghofranipour F, Sanaeinasab H, Amin Shokravi F, Bohle P, Matthews LR. Factors Associated with Unsafe Work Behaviours in an Iranian Petrochemical Company: Perspectives of Workers, Supervisors, and Safety Managers. BMC Public Health. 2020 Jul 31;20(1):1192. doi: 10.1186/s12889-020-09286-0. PMID: 32736619; PMCID: PMC7393823.

11. Arfan I, Rochmawati R, Zulmianto IA. Relationship Characteristics of Welding Workers on Visual Loans in the Welding Industry, Pontianak City. J Ind Hyg Occup Heal. 2019;4(1):58. doi: http://dx.doi.org/10.21111/jihoh.v4i1.3442

12. Peckham TK, Baker MG, Camp JE, Kaufman JD, Seixas NS. Creating a Future for Occupational Health. Ann Work Expo Health. 2017 Jan 1;61(1):3-15. doi: 10.1093/annweh/wxw011. PMID: 28395315.

13. Sakowski P, Marcinkiewicz A. Health Promotion and Prevention in Occupational Health Systems in Europe. Int J Occup Med Environ Health. 2019 Jun 14;32(3):353-361. doi: 10.13075/ijomeh.1896.01384. Epub 2018 Oct 25. PMID: 30356227.

14. Thepaksorn P, Thongjerm S, Incharoen S, Siriwong W, Harada K, Koizumi A. Job Safety Analysis and Hazard Identification for Work Accident Prevention in Para Rubber Wood Sawmills in Southern Thailand. J Occup Health. 2017;59(6):542-51. doi: 10.1539/joh.160204-CS. Epub 2017 Oct 7. PMID: 28993571; PMCID: PMC5721276.

15. Xu Q, Yu F, Li F, Zhou H, Zheng K, Zhang M. Quantitative Differences Between Common Occupational Health Risk Assessment Models. J Occup Health. 2020 Jan;62(1):e12164. doi: 10.1002/1348-9585.12164. PMID: 32949432; PMCID: PMC7507535.

16. Ni G, Zhu Y, Zhang Z, Qiao Y, Li H, Xu N, Deng Y, Yuan Z, Wang W. Influencing Mechanism of Job Satisfaction on Safety Behavior of New Generation of Construction Workers Based on Chinese Context: The Mediating Roles of Work Engagement and Safety Knowledge Sharing. Int J Environ Res Public Health. 2020 Nov 12;17(22):8361. doi: 10.3390/ijerph17228361. PMID: 33198114; PMCID: PMC7697761.

17. Mehrifar Y, Zeverdegani SK, Rismanchian M. Chemical Pollutants in the Respiratory Zone of Welders: Determination of Concentrations and Hazard Analysis. Work. 2020;67(3):591598. doi: 10.3233/WOR-203272. PMID: 32925157.

18. Black M, Karki J, Lee ACK, Makai P, Baral YR, Kritsotakis El, Bernier A, Fossier Heckmann A. The Health Risks of Informal Waste Workers in the Kathmandu Valley: A Cross-Sectional Survey. Public Health. 2019 Jan;166:10-18. doi: 10.1016/j.puhe.2018.09.026. Epub 2018 Nov 9. PMID: 30419409.

19. Saracci R. The Hazards of Hazard Identification in Environmental Epidemiology. Environ Health. 2017 Aug 9;16(1):85. doi: 10.1186/s12940-017-0296-3. PMID: 28793913; PMCID: PMC5550949.

20. Beyene Gebrezgiabher B, Tetemke D, Yetum T. Awareness of Occupational Hazards and Utilization of Safety Measures among Welders in Aksum and Adwa Towns, Tigray Region, Ethiopia, 2013. J Environ Public Health. 2019 Jan 21;2019:4174085. doi: 10.1155/2019/4174085. PMID: 30805014; PMCID: PMC6360553.

21. Dev M, Bhardwaj A. Respiratory Symptoms and Spirometric Abnormalities Among Welders in the Welding Workplace of the Indian Unorganized Sector. Work. 2021;69(3):885-894. doi: 10.3233/WOR-213521. PMID: 34180459.

22. Martin P, Bladier C, Meek B, Bruyere O, Feinblatt E, Touvier M, Watier L, Makowski D. Weight of Evidence for Hazard Identification: A Critical Review of the Literature. Environ Health Perspect. 2018 Jul 17;126(7):076001. doi: 10.1289/EHP3067. PMID: 30024384; PMCID: PMC6108859. 
23. Torén K, Blanc PD, Naidoo RN, Murgia N, Qvarfordt I, Aspevall O, et al. Occupational Exposure to Dust and to Fumes, Work as a Welder and Invasive Pneumococcal Disease Risk. Occup Environ Med. 2020;77(2):57-63. doi: 10.1136/oemed-2019-106175. Epub 2019 Dec 17. PMID: 31848233; PMCID: PMC7029234.

24. Stanislawska M, Janasik B, Kuras R, Malachowska B, Halatek T, Wasowicz W. Assessment of Occupational Exposure to Stainless Steel Welding Fumes - A Human Biomonitoring Study. Toxicol Lett [Internet]. 2020;329(May):47-55. Available from: https://doi.org/10.1016/j.toxlet.2020.04.019

25. Riccelli MG, Goldoni M, Poli D, Mozzoni P, Cavallo D, Corradi M. Welding Fumes, a Risk Factor for Lung Diseases. Int J Environ Res Public Health. 2020;17(7). doi: 10.3390/ijerph17072552. PMID: 32276440; PMCID: PMC7177922.

26. Suárez Sánchez FA, Carvajal Peláez GI, Catalá Alís J. Occupational Safety and Health in Construction: A Review of Applications and Trends. Ind Health. 2017 Jun 8;55(3):210-218. doi: 10.2486/indhealth.2016-0108. Epub 2017 Feb 7. PMID: 28179610; PMCID: PMC5462637.

27. Nelson CA, Elder DE, Elenitsas R, Weir M. Conjunctivitis, Mucosal Erosions, and Moist Cutaneous Plaques. JAAD Case Rep. 2018 Jan 12;4(2):117-119. doi: 10.1016/j.jdcr.2017.04.017. PMID: 29349113; PMCID: PMC5767905.

28. Chartres N, Bero LA, Norris SL. A Review of Methods Used for Hazard Identification and Risk Assessment of Environmental Hazards. Environ Int. 2019 Feb;123:231-239. doi: 10.1016/j.envint.2018.11.060. Epub 2018 Dec 8. PMID: 30537638.

29. Kwaku Tetteh KK, Owusu R, Axame WK. Prevalence and Factors Influencing Eye Injuries among Welders in Accra, Ghana. Adv Prev Med. 2020;2020:1-8. doi: 10.1155/2020/2170247. PMID: 33014472; PMCID: PMC7516735.

30. Falcone LM, Zeidler-Erdely PC. Skin Cancer and Welding. Clin Exp Dermatol. 2019 Mar;44(2):130-134. doi: 10.1111/ced.13783. Epub 2018 Oct 2. PMID: 30280417; PMCID: PMC6415292. 